\title{
Peroxisome proliferator-activated receptors (PPARs) are potential drug targets for cancer therapy
}

\author{
Qian Gou ${ }^{1,2, *}$, Xin Gong ${ }^{2, *}$, Jianhua Jin ${ }^{1, *}$, Juanjuan Shi² and Yongzhong Hou ${ }^{1,2}$ \\ ${ }^{1}$ Department of Oncology, Affiliated Wujin People's Hospital, Jiangsu University, Changzhou, 212017, PR China \\ ${ }^{2}$ Institute of Life Sciences, Jiangsu University, Zhenjiang, 212013, PR China \\ *These authors contributed equally to this work
}

Correspondence to: Yongzhong Hou, email: houyz@ujs.edu.cn

Keywords: PPARs, ligands, cancer therapy, cell signaling

Received: March 04, 2017 Accepted: July 18, 2017

Published: July 27, 2017

Copyright: Gou et al. This is an open-access article distributed under the terms of the Creative Commons Attribution License 3.0 (CC BY 3.0), which permits unrestricted use, distribution, and reproduction in any medium, provided the original author and source are credited.

\begin{abstract}
Peroxisome-proliferator-activated receptors (PPARs) are nuclear hormone receptors including PPARa, PPARס and PPARY, which play an important role in regulating cancer cell proliferation, survival, apoptosis, and tumor growth. Activation of PPARs by endogenous or synthetic compounds regulates tumor progression in various tissues. Although each PPAR isotype suppresses or promotes tumor development depending on the specific tissues or ligands, the mechanism is still unclear. In this review, we summarized the regulative mechanism of PPARs on cancer progression.
\end{abstract}

\section{INTRODUCTION}

As the nuclear hormone receptor, peroxisomeproliferator-activated receptors (PPARs) consist of $\operatorname{PPAR} \alpha, \operatorname{PPAR} \delta$ and PPAR $\gamma$, which are ligand-activated transcription factors. Ligand binding and activation of PPARs heterodimerize with retinoid X receptor (RXRs) and regulate gene transcription. Although PPARs/RXRs bind to the peroxisome-proliferator response element (PPRE, consensus sequence 5'-AGGTCA N AGGTCA-3', $\mathrm{N}$ being any nucleotide) of target gene promoter regions, the each PPAR isotype consensus PPRE motif is different [1-5]. PPARs play a critical role in regulation of obesity, diabetes, atherosclerosis and cancer [6-9]. Even though the PPARs family contains PPAR $\alpha, \operatorname{PPAR} \gamma$ and PPAR $\delta$, they serve as different functions in tumor development. Increasing evidences show that PPAR $\alpha$ [2, 10-12] or $\operatorname{PPAR} \gamma[7,8,13]$ inhibits tumor progression, which acts as tumor suppressors, while some reports show that PPAR $\alpha$ is associated with tumor progression [14-16]. In contrast, PPAR $\delta$ promotes tumor development $[3,6,17]$. PPAR $\delta$ is associated with ulcerative colitis (UC) and Crohn>s disease (CD), which is involved in the progression of colorectal cancer (CRC) $[18,19]$. Endogenous or synthetic ligands can activate PPAR $\delta$ resulting in inflammation and cancer depending on the specific ligands and tissue types [20-22]. Therefore, PPARs can be activated by endogenous or synthetic ligands, subsequently PPARs dependently or independently regulate tumor progression depending on the conditions. In this review, we discussed the progress of PPARs on tumor development.

\section{PPARa}

Lack of PPAR $\alpha$ expressions are associated with shorter breast cancer-specific survival [23]. Our previous investigation shows that PPAR $\alpha$ induces $\mathrm{Bcl} 2$ degradation leading to increased SW480 colonic cancer cell apoptosis in response to chemotherapeutic agents [10]. Glut1 plays a critical role in glucose uptake to regulate cancer cell metabolism, which is widely expressed in most types of cancer cells $[24,25]$. PPAR $\alpha$ can directly inhibit Glut1 transcription by binding Glut1 potential PPRE motif [2]. The synthetic ligands of PPAR $\alpha$ including fenofibrate, clofibrate and wyeth14,643 suppress cell proliferation by inducing apoptosis and cell cycle arrest involved in inhibition of NFкB [26] and activation of caspase-3 [26, 27]. More importantly, the combination of wyeth-14,643 and bezafibrate significantly suppresses lung cancer cell growth [12]. In addition, N-Acetyl-Cysteine (NAC)/PPAR $\alpha$ signaling suppresses Non-small cell lung cancer (NSCLC) cell growth involved in increased the expression of p53 [28]. Although fenofibrate promotes breast cancer cell apoptosis via NFאB-mediated activation 
of caspase-3 and expression of Bad, which is independent of PPAR $\alpha$ activity [27], clofibrate or wyeth14,643 induces hepatocarcinoma HepG2 cell apoptosis [29] and inhibits tumor progression [11] in a PPAR $\alpha$-dependent manner. Moreover, fenofibrate suppresses Huh7 hepatocarcinoma cell proliferation by increasing $\mathrm{C}$-terminal modulator protein (CTMP) expression [27]. In addition to the inhibition of PPAR $\alpha$ on tumor progression, $\mathrm{PPAR}^{-/-}$mice inhibit tumorigenesis involved in increased endogenous angiogenesis inhibitor thrombospondin-1(TSP-1) [14]. Endogenous PPAR $\alpha$ ligand arachidonic acid (AA) enhances breast cancer cell proliferation by up-regulation of cyclin E levels [30]. Nesterified fatty acids (NEFAs) activate PPAR $\alpha$-mediated hepatocarcinogenesis [31]. Therefore, PPAR $\alpha$ antagonist MK886 and NXT629 inhibit chronic lymphocytic leukemia (CLL) cell proliferation $[15,16]$. Other reports show that clofibrate promotes ovarian and prostate cancer progression independent of PPAR $\alpha$ [32]. These findings suggest that different agonists play diversity functions on tumor progression, sometimes they serves as reverse roles, which depends on the tissue types or PPAR $\alpha$ ligands (Figure 1). The discrepancy is associated with the dose of ligands or types of these ligands. Therefore, it is necessary to synthesize the suitable ligands for cancer treatment, which will provide a new drug target for cancer treatment.

\section{PPARס}

Increasing literatures show that aberrant expression of PPAR $\delta$ is associated with pro-inflammatory response and tumor progression [3, 17]. Consistent with this, overexpression of PPAR $\delta$ causes AOM-induced colon tumorigenesis [33], and ultraviolet (UV)-induced PPAR $\delta$ expression leads to Src activation and EGFR/ERK signaling-mediated skin cancer in mice. In contrast, PPAR $\delta^{-/}$mice inhibit DSS-induced colonic inflammation and colitis-associated tumor growth [20], which is associated with inhibition of VEGF expression [34]. Since 14-3-3e interacts with Bad leading to inhibition of cell apoptosis [35], PPAR $\delta$ activation by PGI2, COX-2-derived prostacyclin, directly induces $14-3-3 \varepsilon$ gene expression [36]. COX-2 inhibitors (COXIBs, indomethacin, SC-236 and isoliquiritigenin) suppress PPAR $\delta$ signaling-mediated cell proliferation and tumorigenesis [17]. Wnt/ $\beta$-catenin/ signaling promotes tumorigenesis by inducing PPAR $\delta$ expression $[18,37]$, which is associated with $\operatorname{PPAR} \delta$ mediated cyclin E1 and VEGF expression [38-40]. In contrast, APC inhibits PPAR $\delta$ transcription activity $[18,41]$. PPAR $\delta$ induces VEGF expression leading to PPAR $\delta$ activation by VEGF/PI3K/Akt pathway [40, 42, 43], suggesting that activation of PPAR $\delta$ undergoes a feedback loop [20, 40]. In contrast, PPAR $\delta$-mediated tumor development is inhibited by nitric oxide donating aspirin (NO-ASA) [44]. In addition to PPAR $\delta$-mediated tumor progression, PPAR $\delta$ ligand GW0742 reduces colon or breast cancer event $[45,46]$, this event is reversed in $\mathrm{PPAR}^{-/-}$mice [47]. PPAR $\delta$ promotes HARS-induced senescence leading to inhibition of tumorigenesis [48]. Consistent with this, silence of PPAR $\delta$ results in cell proliferation and tumor growth [49]. Clinical observations show that although PPAR $\delta$ protein levels are lower

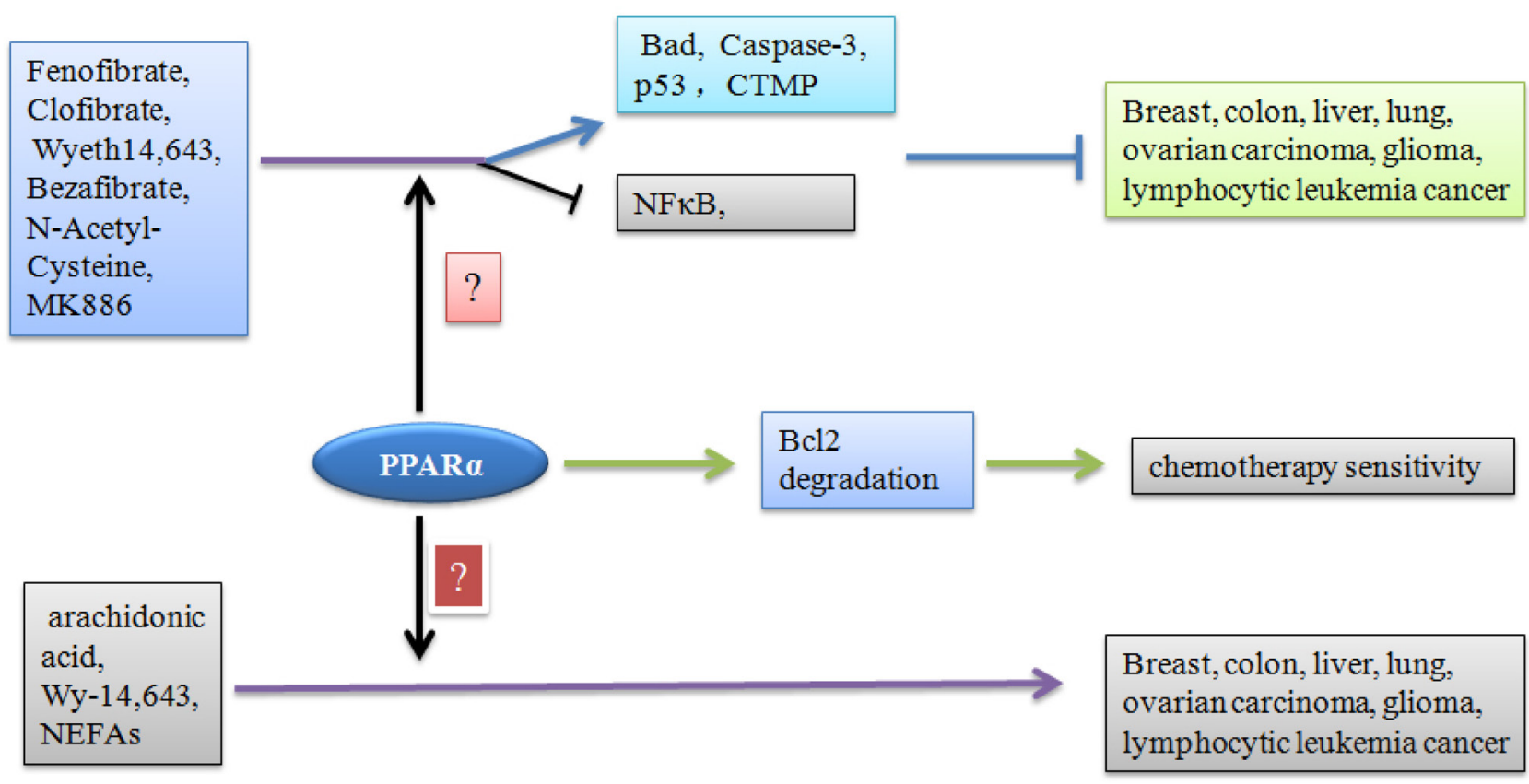

Figure 1: Effect of PPARa ligands on tumor progression. Agonists regulate different types of tumor progression in a PPAR $\alpha$ dependent or independent manner. In addition, PPAR $\alpha$ destructs Bcl2 function leading to increased chemotherapy sensitivity of cancer cells. 


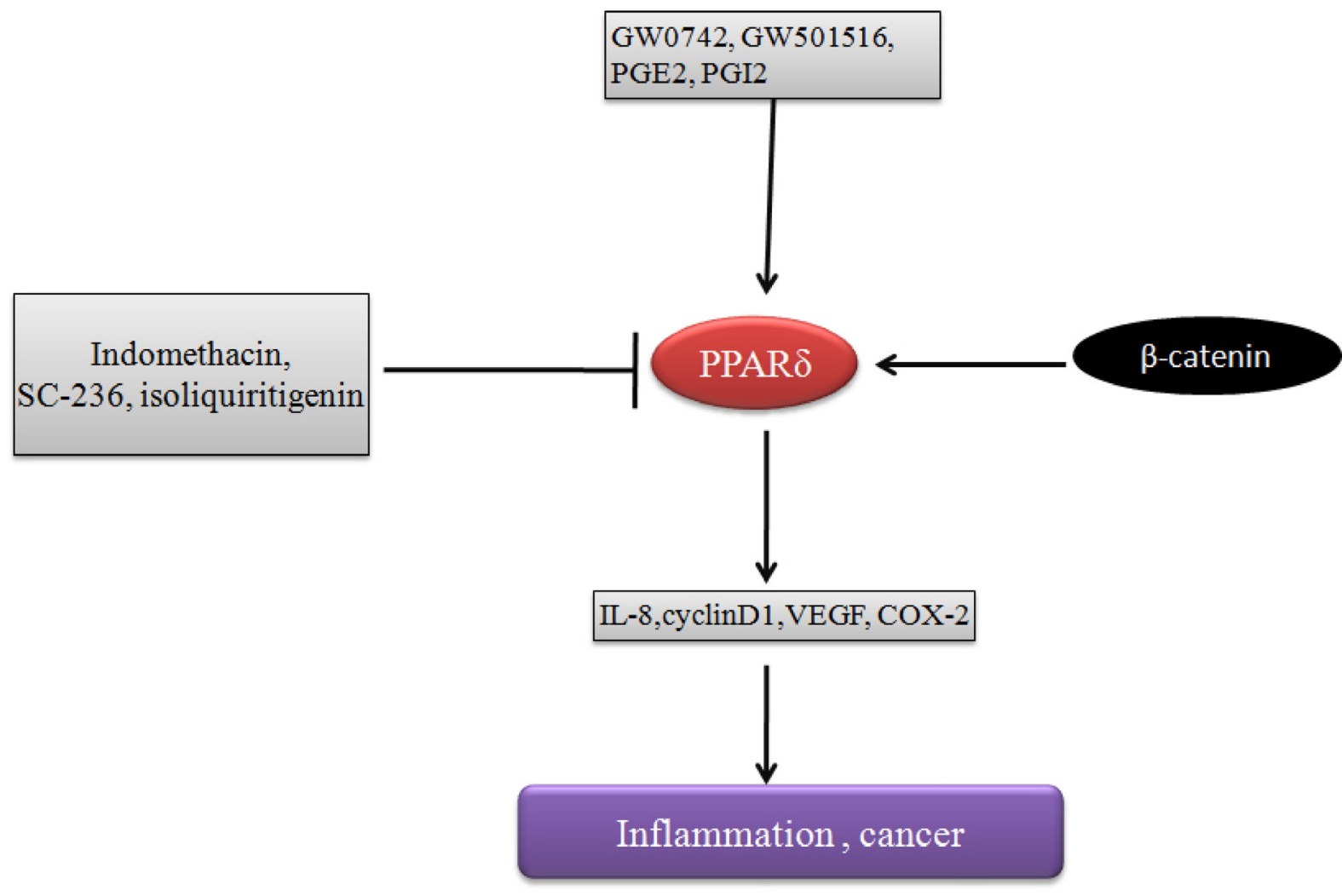

Figure 2: PPAR $\delta$ promotes tumor development. Agonists of PPAR $\delta$ promote inflammation and tumor development by inducing cyclin D1, IL-8, VEGF, COX-2 expression, which is inhibited by the inhibitors of COX-2 such as indomethacin, SC-236, isoliquiritigenin.

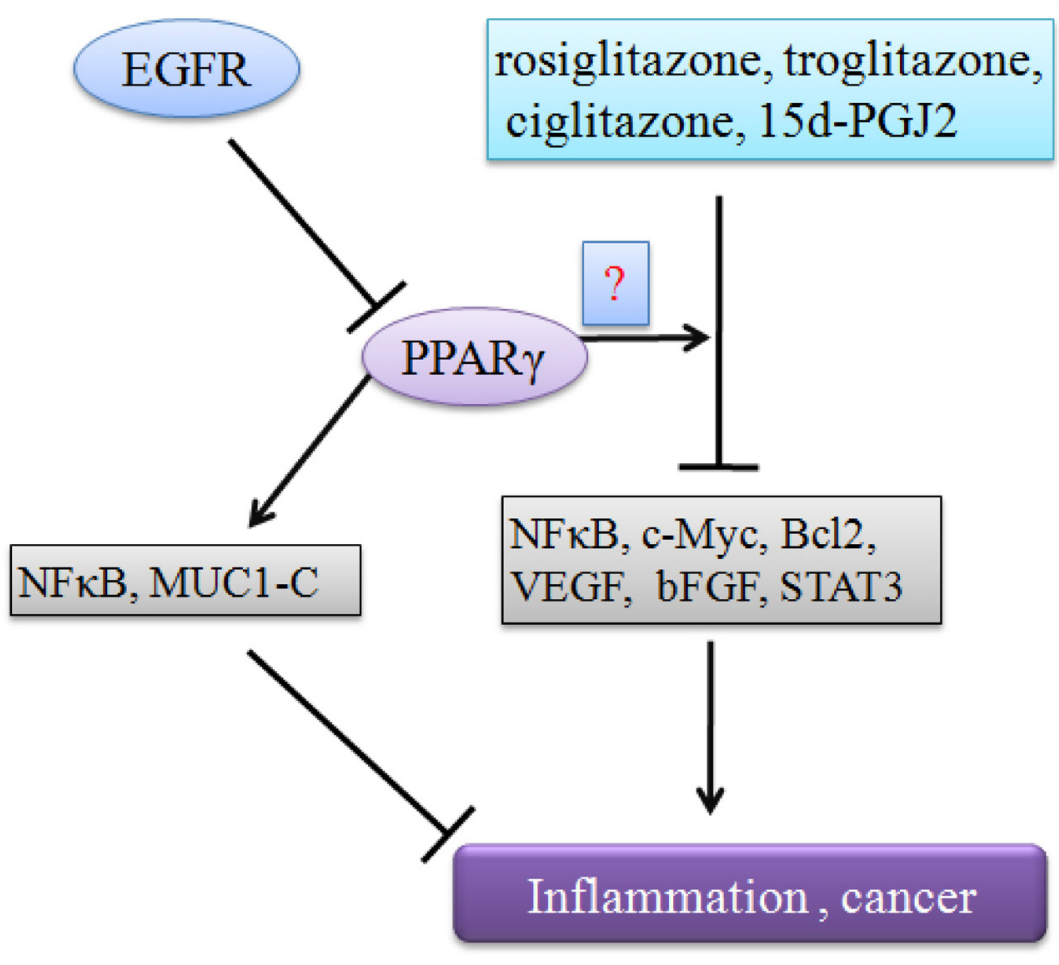

Figure 3: PPAR $\gamma$ negatively regulates tumor progression. Agonists regulate tumor progression in a PPAR $\gamma$ dependent or independent manner, which are involved in inhibition of NFאB, c-Myc, Bcl2, VEGF, bFGF, STAT3. In addition, EGFR can terminate PPAR $\gamma$ antitumor function. 
in human colon adenocarcinomas [50], high PPAR $\delta$ protein levels are benefit of colorectal cancer patients [51]. However, increasing evidences show that PPAR $\delta$ promotes tumor growth $[17,20,21,34,39,40]$. Taken together, PPAR $\delta$ regulates tumor progression involved in multiple signaling pathways (Figure 2). It needs to further determine the physical mechanism of PPAR $\delta$ on tumor development.

\section{PPAR $\gamma$}

PPAR $\gamma$ plays an important role in inflammation, glucose metabolism and cancer [7-9]. While some clinical observations show that PPAR $\gamma$ expression levels are high in advanced prostate cancer (APC) tissues, ovarian, prostate and testicular carcinoma tissues [52-55], it is unclear whether the high levels of PPAR $\gamma$ correlate with favorite outcome in cancer patients. However, other clinical observations show that high PPAR $\gamma$ protein levels are benefit of colonic cancer, cervical carcinoma, follicular thyroid tumor, and esophageal cancer [9]. Consistent with this, overexpression of PPAR $\gamma$ inhibits cell proliferation and tumor growth, but this is reversed in PPAR $\gamma$ silenced cancer cells or activated EGFR signaling [7-9, 13]. PPAR $\gamma$ natural ligand 15-Deoxy$\Delta$-Prostaglandin $\mathrm{J} 2\left(15 \mathrm{~d}_{-} \mathrm{PGJ}_{2}\right)$ induces cell apoptosis involved in inhibition of NFאB (nuclear factor- $\kappa \mathrm{B}$ ) [56]. In addition, some synthetic ligands such asrosiglitazone, troglitazone and ciglitazone suppress cell proliferation by inducing apoptosis, that is involved in reduced c-Myc, $\mathrm{Bcl} 2$, VEGF, and bFGF expression [9]. Moreover, ciglitazone increases the effective of cisplatin on human ovarian cancer treatment [57]. However, ciglitazone and troglitazone suppress ovarian cancer cell proliferation as well as rosiglitazone induces MCF-7 breast cancer cell or pancreatic cancer cell apoptosis independent of PPAR $\gamma$ activity [58-60]. In addition, 15d-PGJ2 and rosiglitazone independent of PPAR $\gamma$ inhibit Janus Kinase (JAK)- signal transducer and activator of transcription (STAT) pathway [61]. These findings suggest that although some ligands show anti-tumor activity, they are independent of PPAR $\gamma$ activity with different mechanism (Figure 3 ). In addition, overexpression or silence of PPAR $\gamma$ suggests that it indeed inhibits tumor growth [7-9]. Therefore, there is a need to develop and test selective PAPR $\gamma$ ligands.

\section{Potential therapeutic targets for cancer}

Increasing literatures show that PPAR $\alpha$ or PPAR $\gamma$ can inhibit tumor progression by multiple pathways, which can be the potential therapeutic targets for cancer treatment, while some agonists suppress tumor progression in a PPAR $\alpha / \gamma$ - independent manner (Figure 1, Figure 3). In contrast, PPAR $\delta$ can promote tumor progression, so the antagonists of PPAR $\delta$ may be the potential therapeutic targets for cancer treatment (Figure 2). Taken together, there is a need to develop and test selective PPARs ligands because of some agonists or antagonists independent of PPARs activity on effect of tumor development.

\section{ACKNOWLEDGMENTS AND FUNDING}

This work was supported by National Natural Science Foundation of China (81672711); by Wujin Sci \& Tech Progran (WS201505); by innovative and entrepreneurial talent of Jiangsu Province.

\section{CONFLICTS OF INTEREST}

None.

\section{REFERENCES}

1. Palmer CN, Hsu MH, Griffin HJ, Johnson EF. Novel sequence determinants in peroxisome proliferator signaling. J Biol Chem. 1995; 270:16114-21.

2. You M, Jin J, Liu Q, Xu Q, Shi J, Hou Y. PPAR $\alpha$ Promotes Cancer Cell Glut1 Transcription Repression. J Cell Biochem. 2017; 118:1556-62.

3. Zhang W, Xu Y, Xu Q, Shi H, Shi J, Hou Y. PPAR $\delta$ promotes tumor progression via activation of Glut1 and SLC1-A5 transcription. Carcinogenesis. 2017; 38:748-55.

4. Khozoie C, Borland MG, Zhu B, Baek S, John S, Hager GL, Shah YM, Gonzalez FJ, Peters JM. Analysis of the peroxisome proliferator-activated receptor- $\beta / \delta(\operatorname{PPAR} \beta / \delta)$ cistrome reveals novel co-regulatory role of ATF4. BMC Genomics. 2012; 13:665.

5. Venkatachalam G, Kumar AP, Yue LS, Pervaiz S, Clement MV, Sakharkar MK. Computational identification and experimental validation of PPRE motifs in NHE1 and MnSOD genes of human. BMC Genomics. 2009; 10:S5.

6. Michalik L, Desvergne B, Wahli W. Peroxisome-proliferatoractivated receptors and cancers: complex stories. Nat Rev Cancer. 2004; 4:61-70.

7. Hou Y, Moreau F, Chadee K. PPAR $\gamma$ is an E3 ligase that induces the degradation of NFkB/p65. Nat Commun. 2012; 3:1300.

8. Hou Y, Gao J, Xu H, Xu Y, Zhang Z, Xu Q, Zhang C. PPAR $\gamma$ E3 ubiquitin ligase regulates MUC1-C oncoprotein stability. Oncogene. 2014; 33:5619-25.

9. Zhang Z, Xu Y, Xu Q, Hou Y. PPAR $\gamma$ against tumors by different signaling pathways. Onkologie. 2013; 36:598-601.

10. Gao J, Liu Q, Xu Y, Gong X, Zhang R, Zhou C, Su Z, Jin J, Shi H, Shi J, Hou Y. PPAR $\alpha$ induces cell apoptosis by destructing Bcl2. Oncotarget. 2015; 6:44635-42. https://doi. org/10.18632/oncotarget.5988.

11. Pozzi A, Ibanez MR, Gatica AE, Yang S, Wei S, Mei S, Falck JR, Capdevila JH. Peroxisomal proliferator-activated receptor-alpha-dependent inhibition of endothelial cell proliferation and tumorigenesis. J Biol Chem. 2007; 282:17685-95. 
12. Skrypnyk N, Chen $\mathrm{X}, \mathrm{Hu} \mathrm{W}, \mathrm{Su} \mathrm{Y}$, Mont S, Yang S, Gangadhariah M, Wei S, Falck JR, Jat JL, Zent R, Capdevila JH, Pozzi A. PPAR $\alpha$ activation can help prevent and treat non-small cell lung cancer. Cancer Res. 2014; 74:621-31.

13. Xu Y, Jin J, Zhang W, Zhang Z, Gao J, Liu Q, Zhou C, Xu Q, Shi H, Hou Y, Shi J. EGFR/MDM2 signaling promotes NF$\kappa \mathrm{B}$ activation via PPAR $\gamma$ degradation. Carcinogenesis. 2016; $37: 215-22$.

14. Kaipainen A, Kieran MW, Huang S, Butterfield C, Bielenberg D, Mostoslavsky G, Mulligan R, Folkman J, Panigrahy D. PPARalpha deficiency in inflammatory cells suppresses tumor growth. PLoS One. 2007; 2:e260.

15. Spaner DE, Lee E, Shi Y, Wen F, Li Y, Tung S, McCaw L, Wong K, Gary-Gouy H, Dalloul A, Ceddia R, Gorzcynski R. PPAR-alpha is a therapeutic target for chronic lymphocytic leukemia. Leukemia. 2013; 27:1090-99.

16. Messmer D, Lorrain K, Stebbins K, Bravo Y, Stock N, Cabrera G, Correa L, Chen A, Jacintho J, Chiorazzi N, Yan XJ, Spaner D, Prasit P, Lorrain D. A Selective Novel Peroxisome Proliferator-Activated Receptor (PPAR)- $\alpha$ Antagonist Induces Apoptosis and Inhibits Proliferation of CLL Cells In Vitro and In Vivo. Mol Med. 2015; 21:410-19.

17. You M, Yuan S, Shi J, Hou Y. PPAR $\delta$ signaling regulates colorectal cancer. Curr Pharm Des. 2015; 21:2956-59.

18. He TC, Chan TA, Vogelstein B, Kinzler KW. PPARdelta is an APC-regulated target of nonsteroidal anti-inflammatory drugs. Cell. 1999; 99:335-45.

19. Peters JM, Morales JL, Gonzalez FJ. Modulation of gastrointestinal inflammation and colorectal tumorigenesis by peroxisome proliferator-activated receptor- $\beta / \delta(\operatorname{PPAR} \beta / \delta)$. Drug Discov Today Dis Mech. 2011; 8:e85-93.

20. Wang D, Fu L, Ning W, Guo L, Sun X, Dey SK, Chaturvedi R, Wilson KT, DuBois RN. Peroxisome proliferator-activated receptor $\delta$ promotes colonic inflammation and tumor growth. Proc Natl Acad Sci USA. 2014; 111:7084-89.

21. Hollingshead HE, Borland MG, Billin AN, Willson TM, Gonzalez FJ, Peters JM. Ligand activation of peroxisome proliferator-activated receptor-beta/delta (PPARbeta/delta) and inhibition of cyclooxygenase 2 (COX2) attenuate colon carcinogenesis through independent signaling mechanisms. Carcinogenesis. 2008; 29:169-76.

22. Berger J, Leibowitz MD, Doebber TW, Elbrecht A, Zhang B, Zhou G, Biswas C, Cullinan CA, Hayes NS, Li Y, Tanen $\mathrm{M}$, Ventre J, Wu MS, et al. Novel peroxisome proliferatoractivated receptor (PPAR) gamma and PPARdelta ligands produce distinct biological effects. J Biol Chem. 1999; 274:6718-25.

23. Baker BG, Ball GR, Rakha EA, Nolan CC, Caldas C, Ellis IO, Green AR. Lack of expression of the proteins GMPR2 and PPAR $\alpha$ are associated with the basal phenotype and patient outcome in breast cancer. Breast Cancer Res Treat. 2013; 137:127-37.

24. Zhao FQ, Keating AF. Functional properties and genomics of glucose transporters. Curr Genomics. 2007; 8:113-28.
25. Young CD, Lewis AS, Rudolph MC, Ruehle MD, Jackman MR, Yun UJ, Ilkun O, Pereira R, Abel ED, Anderson SM. Modulation of glucose transporter 1 (GLUT1) expression levels alters mouse mammary tumor cell growth in vitro and in vivo. PLoS One. 2011; 6:e23205.

26. Zak Z, Gelebart P, Lai R. Fenofibrate induces effective apoptosis in mantle cell lymphoma by inhibiting the TNFalpha/NF-kappaB signaling axis. Leukemia. 2010; 24:1476-86.

27. Li T, Zhang Q, Zhang J, Yang G, Shao Z, Luo J, Fan M, Ni C, $\mathrm{Wu} \mathrm{Z}, \mathrm{Hu} \mathrm{X}$. Fenofibrate induces apoptosis of triple-negative breast cancer cells via activation of NF- $\mathrm{BB}$ pathway. BMC Cancer. 2014; 14:96.

28. Hann SS, Zheng F, Zhao S. Targeting 3-phosphoinositidedependent protein kinase 1 by $\mathrm{N}$-acetyl-cysteine through activation of peroxisome proliferators activated receptor alpha in human lung cancer cells, the role of p53 and p65. J Exp Clin Cancer Res. 2013; 32:43.

29. Maggiora M, Oraldi M, Muzio G, Canuto RA. Involvement of PPAR $\alpha$ and PPAR $\gamma$ in apoptosis and proliferation of human hepatocarcinoma HepG2 cells. Cell Biochem Funct. 2010; 28:571-77.

30. Chang NW, Wu CT, Chen DR, Yeh CY, Lin C. High levels of arachidonic acid and peroxisome proliferator-activated receptor-alpha in breast cancer tissues are associated with promoting cancer cell proliferation. J Nutr Biochem. 2013; 24:274-81.

31. Tanaka N, Moriya K, Kiyosawa K, Koike K, Aoyama T. Hepatitis $\mathrm{C}$ virus core protein induces spontaneous and persistent activation of peroxisome proliferator-activated receptor alpha in transgenic mice: implications for $\mathrm{HCV}$ associated hepatocarcinogenesis. Int J Cancer. 2008; 122:124-31.

32. Wang S, Hannafon BN, Zhou J, Ding WQ. Clofibrate induces heme oxygenase 1 expression through a PPAR $\alpha$-independent mechanism in human cancer cells. Cell Physiol Biochem. 2013; 32:1255-64.

33. Zuo X, Xu M, Yu J, Wu Y, Moussalli MJ, Manyam GC, Lee SI, Liang S, Gagea M, Morris JS, Broaddus RR, Shureiqi I. Potentiation of colon cancer susceptibility in mice by colonic epithelial PPAR- $\delta / \beta$ overexpression. J Natl Cancer Inst. 2014; 106:dju052.

34. Zuo X, Peng Z, Moussalli MJ, Morris JS, Broaddus RR, Fischer SM, Shureiqi I. Targeted genetic disruption of peroxisome proliferator-activated receptor-delta and colonic tumorigenesis. J Natl Cancer Inst. 2009; 101:762-67.

35. Liou JY, Ghelani D, Yeh S, Wu KK. Nonsteroidal antiinflammatory drugs induce colorectal cancer cell apoptosis by suppressing 14-3-3epsilon. Cancer Res. 2007; 67:3185-91.

36. Wu KK, Liou JY. Cyclooxygenase inhibitors induce colon cancer cell apoptosis Via PPARdelta $\longrightarrow$ 14-3-3epsilon pathway. Methods Mol Biol. 2009; 512:295-307.

37. Pollock CB, Rodriguez O, Martin PL, Albanese C, Li X, Kopelovich L, Glazer RI. Induction of metastatic gastric 
cancer by peroxisome proliferator-activated receptor $\delta$ activation. PPAR Res. 2010; 2010:571783.

38. Nagy TA, Wroblewski LE, Wang D, Piazuelo MB, Delgado A, Romero-Gallo J, Noto J, Israel DA, Ogden SR, Correa P, Cover TL, Peek RM Jr. $\beta$-Catenin and p120 mediate $\operatorname{PPAR} \delta$-dependent proliferation induced by Helicobacter pylori in human and rodent epithelia. Gastroenterology. 2011; 141:553-64.

39. Hwang I, Kim J, Jeong S. $\beta$-Catenin and peroxisome proliferator-activated receptor- $\delta$ coordinate dynamic chromatin loops for the transcription of vascular endothelial growth factor A gene in colon cancer cells. J Biol Chem. 2012; 287:41364-73.

40. Jeong E, Koo JE, Yeon SH, Kwak MK, Hwang DH, Lee JY. PPAR $\delta$ deficiency disrupts hypoxia-mediated tumorigenic potential of colon cancer cells. Mol Carcinog. 2014; 53:926-37.

41. Foreman JE, Sorg JM, McGinnis KS, Rigas B, Williams JL, Clapper ML, Gonzalez FJ, Peters JM. Regulation of peroxisome proliferator-activated receptor-beta/delta by the APC/beta-CATENIN pathway and nonsteroidal antiinflammatory drugs. Mol Carcinog. 2009; 48:942-52.

42. Wang D, Wang H, Shi Q, Katkuri S, Walhi W, Desvergne B, Das SK, Dey SK, DuBois RN. Prostaglandin E(2) promotes colorectal adenoma growth via transactivation of the nuclear peroxisome proliferator-activated receptor delta. Cancer Cell. 2004; 6:285-95.

43. Wang D, Wang H, Guo Y, Ning W, Katkuri S, Wahli W, Desvergne B, Dey SK, DuBois RN. Crosstalk between peroxisome proliferator-activated receptor delta and VEGF stimulates cancer progression. Proc Natl Acad Sci USA. 2006; 103:19069-74.

44. Ouyang N, Williams JL, Rigas B. NO-donating aspirin isomers downregulate peroxisome proliferator-activated receptor (PPAR)delta expression in $\mathrm{APC}(\mathrm{min} /+)$ mice proportionally to their tumor inhibitory effect: implications for the role of PPARdelta in carcinogenesis. Carcinogenesis. 2006; 27:232-39.

45. Marin HE, Peraza MA, Billin AN, Willson TM, Ward JM, Kennett MJ, Gonzalez FJ, Peters JM. Ligand activation of peroxisome proliferator-activated receptor beta inhibits colon carcinogenesis. Cancer Res. 2006; 66:4394-401.

46. Yao PL, Morales JL, Zhu B, Kang BH, Gonzalez FJ, Peters $\mathrm{JM}$. Activation of peroxisome proliferator-activated receptor$\beta / \delta$ (PPAR- $\beta / \delta$ ) inhibits human breast cancer cell line tumorigenicity. Mol Cancer Ther. 2014; 13:1008-17.

47. Hollingshead HE, Morimura K, Adachi M, Kennett MJ, Billin AN, Willson TM, Gonzalez FJ, Peters JM. PPARbeta/ delta protects against experimental colitis through a ligandindependent mechanism. Dig Dis Sci. 2007; 52:2912-19.

48. Zhu B, Ferry CH, Blazanin N, Bility MT, Khozoie C, Kang BH, Glick AB, Gonzalez FJ, Peters JM. PPAR $\beta / \delta$ promotes HRAS-induced senescence and tumor suppression by potentiating p-ERK and repressing p-AKT signaling. Oncogene. 2014; 33:5348-59.

49. Yang L, Zhou J, Ma Q, Wang C, Chen K, Meng W, Yu Y, Zhou Z, Sun X. Knockdown of PPAR $\delta$ gene promotes the growth of colon cancer and reduces the sensitivity to bevacizumab in nude mice model. PLoS One. 2013; 8:e60715.

50. Foreman JE, Chang WC, Palkar PS, Zhu B, Borland MG, Williams JL, Kramer LR, Clapper ML, Gonzalez FJ, Peters JM. Functional characterization of peroxisome proliferatoractivated receptor- $\beta / \delta$ expression in colon cancer. Mol Carcinog. 2011; 50:884-900.

51. Yang L, Zhang H, Zhou ZG, Yan H, Adell G, Sun XF. Biological function and prognostic significance of peroxisome proliferator-activated receptor $\delta$ in rectal cancer. Clin Cancer Res. 2011; 17:3760-70.

52. Rogenhofer S, Ellinger J, Kahl P, Stoehr C, Hartmann A, Engehausen D, Wieland WF, Müller SC, Hofstädter F, Walter B. Enhanced expression of peroxisome proliferate-activated receptor gamma (PPAR- $\gamma$ ) in advanced prostate cancer. Anticancer Res. 2012; 32:3479-83.

53. Zhang GY, Ahmed N, Riley C, Oliva K, Barker G, Quinn MA, Rice GE. Enhanced expression of peroxisome proliferator-activated receptor gamma in epithelial ovarian carcinoma. Br J Cancer. 2005; 92:113-19.

54. Kubota T, Koshizuka K, Williamson EA, Asou H, Said JW, Holden S, Miyoshi I, Koeffler HP. Ligand for peroxisome proliferator-activated receptor gamma (troglitazone) has potent antitumor effect against human prostate cancer both in vitro and in vivo. Cancer Res. 1998; 58:3344-52.

55. Hase T, Yoshimura R, Mitsuhashi M, Segawa Y, Kawahito Y, Wada S, Nakatani T, Sano H. Expression of peroxisome proliferator-activated receptors in human testicular cancer and growth inhibition by its agonists. Urology. 2002; 60:542-47.

56. Fujita M, Tohji C, Honda Y, Yamamoto Y, Nakamura T, Yagami T, Yamamori M, Okamura N. Cytotoxicity of 15-deoxy- $\Delta(12,14)$-prostaglandin $J(2)$ through PPAR $\gamma$ independent pathway and the involvement of the JNK and Akt pathway in renal cell carcinoma. Int J Med Sci. 2012; 9:555-66.

57. Yokoyama Y, Xin B, Shigeto T, Mizunuma H. Combination of ciglitazone, a peroxisome proliferator-activated receptor gamma ligand, and cisplatin enhances the inhibition of growth of human ovarian cancers. J Cancer Res Clin Oncol. 2011; 137:1219-28.

58. Al-Alem L, Southard RC, Kilgore MW, Curry TE. Specific thiazolidinediones inhibit ovarian cancer cell line proliferation and cause cell cycle arrest in a PPAR $\gamma$ independent manner. PLoS One. 2011; 6:e16179.

59. Green DR. Apoptotic pathways: the roads to ruin. Cell. 1998; 94:695-98.

60. Ricciardi S, Mey V, Nannizzi S, Pasqualetti G, Crea F, Del Tacca M, Danesi R. Synergistic cytotoxicity and molecular interaction on drug targets of sorafenib and gemcitabine in human pancreas cancer cells. Chemotherapy. 2010; 56:303-12.

61. Park EJ, Park SY, Joe EH, Jou I. 15d-PGJ2 and rosiglitazone suppress Janus kinase-STAT inflammatory signaling through induction of suppressor of cytokine signaling 1 (SOCS1) and SOCS3 in glia. J Biol Chem. 2003; 278:14747-52. 